\title{
Human ATP-binding cassette (ABC) transporter family
}

\author{
Vasilis Vasiliou,' Konstandinos Vasiliou' and Daniel W. Nebert ${ }^{2 *}$ \\ 'Molecular Toxicology and Environmental Health Sciences Program, Department of Pharmaceutical Sciences, University of Colorado \\ Denver, Aurora, CO 80045, USA \\ ${ }^{2}$ Department of Environmental Health and Center for Environmental Genetics (CEG), University of Cincinnati Medical Center, \\ Cincinnati, OH 45267-0056, USA \\ *Correspondence to: Tel: +1 513821 4664; Fax: +1 513558 0925; E-mail: dan.nebert@uc.edu
}

Date received (in revised form): 23rd February 2009

\begin{abstract}
There exist four fundamentally different classes of membrane-bound transport proteins: ion channels; transporters; aquaporins; and ATP-powered pumps. ATP-binding cassette (ABC) transporters are an example of ATPdependent pumps. $A B C$ transporters are ubiquitous membrane-bound proteins, present in all prokaryotes, as well as plants, fungi, yeast and animals. These pumps can move substrates in (influx) or out (efflux) of cells. In mammals, $A B C$ transporters are expressed predominantly in the liver, intestine, blood-brain barrier, blood-testis barrier, placenta and kidney. $A B C$ proteins transport a number of endogenous substrates, including inorganic anions, metal ions, peptides, amino acids, sugars and a large number of hydrophobic compounds and metabolites across the plasma membrane, and also across intracellular membranes. The human genome contains $49 A B C$ genes, arranged in eight subfamilies and named via divergent evolution. That $A B C$ genes are important is underscored by the fact that mutations in at least II of these genes are already known to cause severe inherited diseases (eg cystic fibrosis and X-linked adrenoleukodystrophy [X-ALD]). ABC transporters also participate in the movement of most drugs and their metabolites across cell surface and cellular organelle membranes; thus, defects in these genes can be important in terms of cancer therapy, pharmacokinetics and innumerable pharmacogenetic disorders.
\end{abstract}

Keywords: human genome, human ATP-binding cassette (ABC) transporter gene family, genetic polymorphism, evolution, drug transport, cancer chemotherapy

\section{Introduction}

Membrane transport proteins can be divided into four types: ion channels; transporters; aquaporins; and ATP-powered pumps (http://www.ncbi.nlm. nih.gov/books/bv.fcgi?rid=mcb.figgrp.4031). Genes from all four categories are ancient - with members present in most, if not all, prokaryotes, as well as in virtually all cell types of all eukaryotes. Transporters in eukaryotic cells move ions, sugars, amino acids and other molecules across all cellular and organelle membranes (cell surface, mitochondrial, endoplasmic reticulum, Golgi apparatus and other vesicles) - with the possible exception of nuclear membranes (which have pores). The portion of the cell exposed to the lumen is called the apical surface; the rest of the cell (ie sides and base) makes up the basolateral surface. Movement of ions or other molecules into the cell is called influx; movement of ions or other molecules out of the cell is termed efflux.

Membrane transport proteins can be either passive or active. Passive transporters (also called uniporters or facilitative transporters) transport substrates down a concentration gradient. By contrast, 
active transporters (or cotransporters) couple the movement of one type of ion or molecule against its concentration gradient, to the movement of another ion or molecule down its concentration gradient. Like ATP pumps, cotransporters mediate coupled reactions in which an energetically unfavourable reaction is coupled to an energetically favourable reaction. When the transported molecule and cotransported ion move in the same direction across a membrane, the transporter is called a symporter; when they move in opposite directions, the transporter is called an antiporter (or exchanger). If the intracellular net charge following transport becomes more negative, the process is termed electronegative; if the intracellular net charge becomes more positive, the process is called electropositive; if the resulting intracellular net charge remains unchanged, the process is termed electroneutral.

Ion channels are pore-forming membrane proteins that help to establish and maintain smallvoltage gradients across plasma membrane surfaces of all living cells. As such, they regulate the cell's electric potential by allowing the flow of ions down their electrochemical gradient. Ion channels usually occur in the closed state. Cationic and anionic substrates are transferred down their electrochemical gradients at extremely high efficiencies (as much as $10^{8} \mathrm{sec}^{-1}$ ). More than 400 genes are known to encode ion channel subunits. ${ }^{1}$

Transporters facilitate the movement of a specific substrate - either with or against its concentration gradient - and the conformational change in the transporter protein is important in this transfer process. Transporters move molecules at only about $10^{2}-10^{4} \mathrm{sec}^{-1}$, a rate much slower than that associated with channel proteins. Many of these transporters belong to the solute-carrier (SLC) gene superfamily, and include passive transporters, symporters and antiporters, as well as mitochondrial and vesicular transporters. The SLC superfamily comprises 55 gene families, having at least 362 putatively functional protein-coding genes. $^{2}$

Aquaporins are a unique class of transporter. These proteins are bi-directional membrane channels which transport water, but they are not ion channels because the $\mathrm{H}_{2} \mathrm{O}$ is transported as an uncharged molecule and not as an ion. The driving force for aquaporins is the presence of osmotic gradients across membranes. ${ }^{3}$ There are 13 putatively functional $A Q P$ genes in the human genome (http:// www.genenames.org/).

ATP-powered pumps include the ATP-binding cassette (ABC) pumps. These pumps use energy released by ATP hydrolysis to move substrates across membranes in or out of cells or into cellular vesicles, against their electrochemical gradient. ABC pumps constitute a large, diverse and ubiquitous superfamily. Most $A B C$ genes encode membrane-bound proteins that participate directly in the transport of a wide range of molecules across membranes. ${ }^{4}$ ABC transporters can broadly be categorised as importers or exporters, depending on the direction of transport relative to the cytoplasm. ${ }^{5}$ Plants carry a particularly large complement of ABC proteins; these pumps are associated with the need to establish steep concentration gradients of solutes across cellular membranes, as well as metabolic versatility. Plant ABC pumps are not only involved in the transport of hormones, lipids, secondary metabolites, metals and xenobiotics, ${ }^{4}$ but also contribute to osmolality and ion channel and phytoalexin functions (plant-pathogen interactions). Even the evolution of seed size in the tomato has been associated with an $A B C$ transporter gene. ${ }^{6}$

\section{Details of the $A B C$ proteins}

By definition, ABC proteins possess an ATP binding cassette, also known as the 'nucleotide-binding domain' (NBD). The NBD contains several highly conserved motifs, including the Walker A and Walker $B$ sequences, the $\mathrm{ABC}$ signature motif, the $\mathrm{H}$ loop and the $\mathrm{Q}$ loop. ABC transporters also contain transmembrane domains (TMDs), each of which comprises several hydrophobic $\alpha$-helices. The ABC transporter core unit consists of four domains, two NBDs and two TMDs. The two NBDs together bind and hydrolyse ATP (thereby providing the driving force for transport), while the TMDs participate in substrate recognition and translocation across the lipid membrane. ${ }^{4}$ Some $A B C$ genes encode proteins that are 'half-transporters' (meaning that two 
subunits bind as homodimers or a heterodimer), whereas others are 'full-transporters'.

\section{The human $A B C$ gene family}

The human genome carries 49 ABC genes, arranged in seven subfamilies, designated $A$ to $G$ (Figure 1 and Table 1). This diverse transporter family has members that play pivotal roles in many cellular processes. For example, ABC transporters are responsible for the multidrug resistance of cancer cells. ${ }^{7}$ ABC proteins also transport a number of substrates, including metal ions, peptides, amino acids, sugars and a large number of hydrophobic compounds and metabolites across the plasma membrane, and also intracellular membranes. The function of each $A B C$ gene product, when known, is listed in the far right column of Table 2 . At the present time, 21 ABC pseudogenes have been identified ${ }^{8}$ and localised to chromosomal regions (Table 3 ).

Mutations in at least $11 A B C$ genes to date are clearly associated with inherited diseases: ${ }^{10}$ Tangier disease T1 (ABCA1); Stargardt disease, retinitis pigmentosa and age-related macular degeneration $(A B C A 4)$; progressive familial intrahepatic cholestasis (ABCB11); Dubin-Johnson syndrome (ABCC2); pseudoxanthoma elasticum ( $A B C C 6)$; cystic fibrosis (ABCC7); X-linked adrenoleukodystrophy (ALD) ( $A B C D 1$ and $A B C D 2)$; some forms of Zellweger syndrome ( $A B C D 3$ and $A B C D 2$ ) and sitosterolaemia (a rare lipid metabolic disorder inherited as an autosomal recessive trait) ( $A B D G 5$ and $A B C G 8)$. An additional eight $A B C$ genes have been implicated in, or are candidates for, other metabolic inherited diseases (http://nutrigene.4t.com:80/humanabc.htm).

\section{Clans: Comments on sequence identity}

The ABC family is a member of the P-loop-containing nucleoside-triphosphate hydrolase clan (CL0023). The definition of the clan in the Pfam database is: 'A collection of evolutionarily-related Pfam entries. This relationship may be defined by similarity of protein sequence, tertiary structure or profile, as defined by the Hidden Markov model'. ${ }^{11,12}$
At the moment, clan CL0023 contains 55 protein families, including the ABC family.

\section{Subfamily $A$ of the $A B C$ family (ABCA)}

Subfamily A contains 12 genes, most of which appear to be involved in lipid trafficking in many diverse organs and cell types. Among the largest of the $\mathrm{ABC}$ transporters, some of the ABCA proteins weigh in at more than 2,100 amino acids in length. ${ }^{10}$ In fact, the predicted ABCA13 protein contains 5,058 residues, making it the largest $\mathrm{ABC}$ protein known. Mutations in specific $A B C A$ genes lead to genetic disorders, ${ }^{13}$ such as Tangier disease T1, familial high-density lipoprotein (HDL) deficiency, Stargardt disease-1, age-related macular degeneration and retinitis pigmentosa (Table 2).

\section{Subfamily $B$ of the ABC family (ABCB)}

This subfamily of 11 genes is unique to mammals; there are four full-transporters and seven halftransporters. Several of the B family members are known to confer multidrug resistance in cancer cells; hence, subfamily $\mathrm{B}$ has also been called the 'MDR family of ABC transporters'. ${ }^{10}$ Mutations in $A B C B$ genes have been implicated in ankylosing spondylitis, diabetes type 2, coeliac disease, lethal neonatal syndrome, X-linked sideroblastic anaemia with ataxia, and several cholestatic liver diseases of infancy (Table 2). Many of these genotypephenotype association studies suggesting the involvement of $A B C B$ genes, however, are likely to represent false-positive, inconclusive or underpowered studies, and need further replication in other large cohorts before they can be regarded as 'informative' and conclusive. ${ }^{14}$

Recent genome-wide searches for positive selection in the human genome have suggested the possibility that the metabolism and transport of foreign chemicals (foodstuffs, plant metabolites and drugs) might have undergone natural selection. ${ }^{15-17}$ In this regard, the 230-kilobase $(\mathrm{kb})$ cluster of four cytochrome $\mathrm{P} 450$ 3A $(C Y P 3 A)$ functional genes 


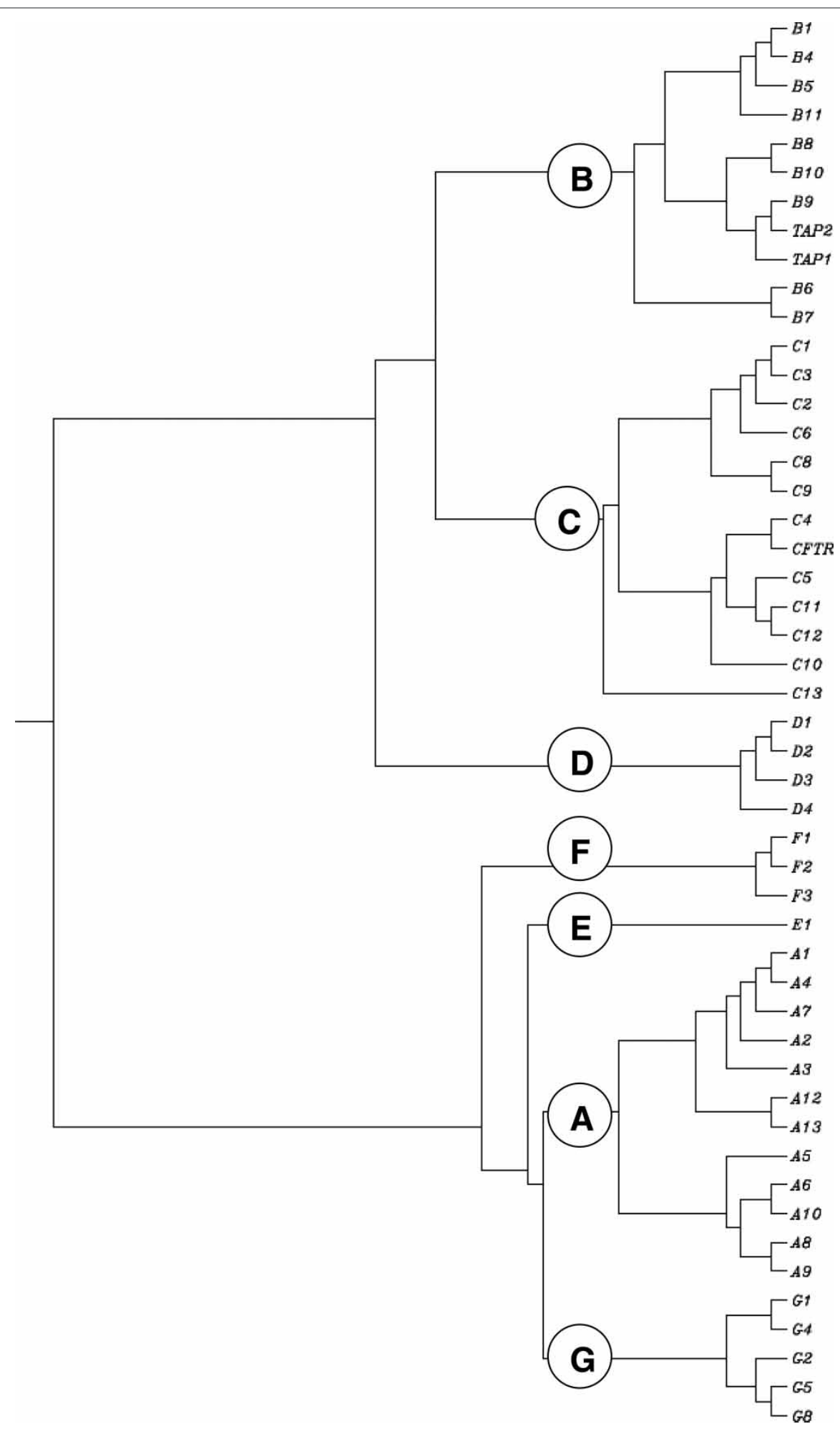

Figure I. Clustering dendrogram of the human ATP-binding cassette $(A B C)$ transporter genes. The root ' $A B C$ ' is omitted from the figure to simplify it. Thus, the correct gene name for ' $B I$ ' is $A B C B I$, for ' $B 4$ ' is $A B C B 4$, and so forth. 
Table I. Human $A B C$ gene subfamilies

\begin{tabular}{|l|ccc|}
\hline $\begin{array}{l}\text { Subfamily } \\
\text { name }\end{array}$ & Aliases & $\begin{array}{c}\text { Number } \\
\text { of genes }\end{array}$ & $\begin{array}{c}\text { Number of } \\
\text { pseudogenes }\end{array}$ \\
\hline$A B C A$ & ABCI & 12 & 5 \\
\hline$A B C B$ & MDR & 11 & 4 \\
\hline$A B C C$ & MRP & 13 & 2 \\
\hline$A B C D$ & ALD & 4 & 4 \\
\hline$A B C E$ & OABP & 1 & 2 \\
\hline$A B C F$ & GGN20 & 3 & 2 \\
\hline$A B C G$ & White & 5 & 2 \\
\hline Total & & 49 & 21 \\
\hline
\end{tabular}

and two pseudogenes, located at chromosome 7 , is only $119 \mathrm{~kb}$ distant from the $A B C B 1$ gene (the transcript of which spans $210 \mathrm{~kb}$ ). Moreover, the CYP3A enzymes and ABCB1 transporter appear to have very similar substrate profiles, and both are regulated by the pregnane $\mathrm{X}$ receptor $(\mathrm{PXR})$ in the liver, intestine, lung and kidney. ${ }^{18}$ In addition, positive selection has recently been noted in the ligand-binding domain of PXR, ${ }^{19}$ lending further credence to the possible co-evolution of these two nearby loci, in response to dietary pressures. Future investigators should look carefully for similar patterns of possible co-evolution by other drugmetabolising genes and drug-transporter genes.

\section{Subfamily $C$ of the $A B C$ family $(A B C C)$}

Subfamily $\mathrm{C}$ includes the cystic fibrosis gene (CFTR, also called ABCC7) plus 12 other genes that encode transporters associated with multidrug resistance. The diverse activities of ABCC transporters include ion-channel and toxin excretion activity and reception on the cell surface; toxin excretion involves various fungal and bacterial toxins. ${ }^{10}$ Mutations in one or more of the $A B C C$ genes have been implicated in multidrug resistance, Dubin-Johnson syndrome, congenital bilateral aplasia of the vas deferens, diabetes type 2 and paroxysmal kinesigenic choreoathetosis - as well as autosomal recessive diseases such as cystic fibrosis, pseudoxanthoma elasticum and hyperinsulinaemic hypoglycaemia of infancy (Table 2).

The CFTR encodes a unique $\mathrm{ABC}$ transporter protein. Recent data suggest that CFTR channel activity evolved by converting the conformational changes associated with ATP binding and hydrolysis (found in 'true' ABC pumps) into an open permeation pathway, by means of intra-protein interactions that stabilise the open state. ${ }^{20}$ The 'selective pressure' in the environment that might have encouraged this unique CFTR protein to evolve to exhibit this characteristic has been suggested to be severe infection - that is, cholera epidemics. ${ }^{21}$

\section{Subfamily $D$ of the $A B C$ family $(A B C D)$}

Also known as the peroxisomal or ALD transporters, this subfamily contains four genes that encode halftransporters; these subunits form homodimers or heterodimers to make a functional unit. These four human half-transporter genes code for at least 49 distinct proteins by means of 102 alternatively spliced transcripts. ${ }^{10}$ Mutations in $A D B D$ genes are known to cause ALD and Zellweger syndrome (Table 2).

\section{Subfamily $E$ of the $A B C$ family (ABCE)}

ABCE1 is the single member in this family which is an organic anion-binding protein (its trivial name is $\mathrm{OABP}$ ), sometimes confused with the 11 SLCO genes that encode solute-carrier organic anion transporters. ${ }^{2}$ ABCE1 has an ATP-binding domain but lacks the transmembrane domain, making it unlikely that this protein functions as a transporter. Because of 15 alternatively spliced transcripts, the ABCE1 gene encodes five distinct proteins. ${ }^{10}$ ABCE1 has been found to block the activity of ribonuclease L. Activation of ribonuclease L leads to inhibition of protein synthesis in a pivotal pathway involving viral interferon action; hence, ABCE1 functions to promote interferon activity. 
Table 2. Human $A B C$ transporter genes, and their functions, as listed in the HGNC database

\begin{tabular}{|c|c|c|c|c|c|}
\hline Gene & $\begin{array}{l}\text { Chromosome } \\
\text { location }\end{array}$ & Exons & AA & $\begin{array}{l}\text { Accession } \\
\text { number }\end{array}$ & Function \\
\hline$A B C A I$ & $9 q 31.1$ & 36 & 2261 & NM005502 & Cholesterol efflux onto HDL \\
\hline$A B C A 2$ & $9 q 34$ & 27 & 2436 & NM00I606 & Drug resistance \\
\hline$A B C A 3$ & $16 p \mid 3.3$ & 26 & 1704 & NM00I089 & Multidrug resistance \\
\hline$A B C A 4$ & Ip22 & 38 & 2273 & NM000350 & $\begin{array}{l}\text { N-retinylidene-phosphatidylethanolamine } \\
\text { (PE) efflux }\end{array}$ \\
\hline$A B C A 5$ & $17 q 24.3$ & 31 & 1642 & NM0I8672 & $\begin{array}{l}\text { Urinary diagnostic marker for prostatic } \\
\text { intraepithelial neoplasia (PIN) }\end{array}$ \\
\hline$A B C A 6$ & $17 q 24.3$ & 35 & 1617 & NM080284 & Multidrug resistance \\
\hline$A B C A 7$ & $19 p \mid 3.3$ & 31 & 2146 & NM019112 & Cholesterol efflux \\
\hline$A B C A 8$ & $17 q 24$ & 31 & $|58|$ & NM007I68 & Transports certain lipophilic drugs \\
\hline$A B C A 9$ & $17 q 24.2$ & 31 & 1624 & NM080283 & $\begin{array}{l}\text { Might play a role in monocyte } \\
\text { differentiation and macrophage lipid } \\
\text { homeostasis }\end{array}$ \\
\hline$A B C A / 0$ & $17 q 24$ & 27 & 1543 & NM080282 & Cholesterol-responsive gene \\
\hline$A B C A / 2$ & $2 q 34$ & 37 & 2595 & NMI73076 & Has implications for prenatal diagnosis \\
\hline$A B C A / 3$ & $7 p \mid 2.3$ & 36 & 5058 & NMI5270I & Inherited disorder affecting the pancreas \\
\hline$A B C B I$ & $7 q 21.1$ & 20 & 1280 & NM000927 & Multidrug resistance \\
\hline$A B C B 2(T A P I)$ & $6 p 21.3$ & II & 808 & NM000593 & Peptide transport \\
\hline ABCB3 (TAP2) & $6 p 21.3$ & 11 & 703 & NM000544 & Peptide transport \\
\hline$A B C B 4$ & $7 q 21.1$ & 25 & 1279 & NM000443 & Phosphatidylcholine (PC) transport \\
\hline$A B C B 5$ & $7 p 15.3$ & 17 & 812 & NMI78559 & Melanogenesis \\
\hline$A B C B 6$ & $2 q 36$ & 19 & 842 & NM005689 & Iron transport \\
\hline$A B C B 7$ & $X q|2-q| 3$ & 14 & 753 & NM004299 & $\mathrm{Fe} / \mathrm{S}$ cluster transport \\
\hline$A B C B 8$ & $7 q 36$ & 15 & 718 & NM007I88 & $\begin{array}{l}\text { Intracellular peptide trafficking across } \\
\text { membranes }\end{array}$ \\
\hline$A B C B 9$ & $12 q 24$ & 12 & 766 & NM019625 & Located in lysosomes \\
\hline$A B C B / 0$ & Iq42.13 & 13 & 738 & NM0I 2089 & $\begin{array}{l}\text { Export of peptides derived from } \\
\text { proteolysis of inner-membrane proteins }\end{array}$ \\
\hline$A B C B / I$ & $2 q 24$ & 26 & $|32|$ & NM003742 & Bile salt transport \\
\hline$A B C C I$ & $16 p \mid 3.1$ & 31 & $|53|$ & NM004996 & Drug resistance \\
\hline$A B C C 2$ & $10 q 24$ & 26 & 1545 & NM000392 & Organic anion efflux \\
\hline
\end{tabular}


Table 2. Continued

\begin{tabular}{|c|c|c|c|c|c|}
\hline Gene & $\begin{array}{l}\text { Chromosome } \\
\text { location }\end{array}$ & Exons & AA & $\begin{array}{l}\text { Accession } \\
\text { number }\end{array}$ & Function \\
\hline$A B C C 3$ & $17 q 22$ & 19 & 1527 & NM003786 & Drug resistance \\
\hline$A B C C 4$ & $13 q 32$ & 19 & 1325 & NM005845 & Nucleoside transport \\
\hline$A B C C 5$ & $3 q 27$ & 25 & 1437 & NM005688 & Nucleoside transport \\
\hline$A B C C 6$ & $16 p \mid 3.1$ & 28 & 1503 & NM00II7I & Expressed primarily in liver and kidney \\
\hline ABCC7 (CFTR) & $7 q 31.2$ & 23 & 1480 & NM000492 & $\begin{array}{l}\text { Chloride ion channel (same as CFTR gene } \\
\text { in cystic fibrosis) }\end{array}$ \\
\hline$A B C C 8$ & IIp|5.| & 30 & $|58|$ & NM000352 & Sulfonylurea receptor \\
\hline$A B C C 9$ & $12 p \mid 2.1$ & 32 & 1549 & NM00569I & $\begin{array}{l}\text { Encodes the regulatory SUR2A subunit of } \\
\text { the cardiac } \mathrm{K}^{+} \text {(ATP) channel }\end{array}$ \\
\hline$A B C C I O$ & $6 p 21.1$ & 19 & 1464 & NM033450 & Multidrug resistance \\
\hline$A B C C I I$ & $16 q 12.1$ & 25 & 1382 & NM033I5I & Drug resistance in breast cancer \\
\hline$A B C C I 2$ & $16 q \mid 2.1$ & 25 & 1359 & NM033226 & Multidrug resistance \\
\hline$A B C C I 3$ & $2|q| \mid .2$ & 6 & 325 & NM00387 & $\begin{array}{l}\text { Encodes a polypeptide of unknown } \\
\text { function }\end{array}$ \\
\hline$A B C D /$ & $X q 28$ & 9 & 745 & NM000033 & $\begin{array}{l}\text { Very-long-chain fatty acid (VLCFA) } \\
\text { transport }\end{array}$ \\
\hline$A B C D 2$ & $|2 q||-q| 2$ & 10 & 740 & NM005I64 & $\begin{array}{l}\text { Major modifier locus for clinical diversity } \\
\text { in X-linked ALD (X-ALD) }\end{array}$ \\
\hline$A B C D 3$ & $|p 22-p 2|$ & 16 & 659 & NM002858 & $\begin{array}{l}\text { Involved in import of fatty acids and/or } \\
\text { fatty acyl-coenzyme As into the } \\
\text { peroxisome }\end{array}$ \\
\hline$A B C D 4$ & $14 q 24$ & 19 & 606 & NM005050 & May modify the ALD phenotype \\
\hline$A B C E I$ & $4 q 31$ & 14 & 599 & NM002940 & Oligoadenylate-binding protein \\
\hline$A B C F I$ & $6 p 21.33$ & 19 & 845 & NM00I02509I & Susceptibility to autoimmune pancreatitis \\
\hline$A B C F 2$ & $7 q 36$ & 14 & 634 & NM005692 & $\begin{array}{l}\text { Tumour suppression at metastatic sites and } \\
\text { in endocrine pathway for breast cancer/ } \\
\text { drug resistance }\end{array}$ \\
\hline$A B C F 3$ & $3 q 27.1$ & 21 & 709 & NM018358 & $\begin{array}{l}\text { Also present in promastigotes (one of five } \\
\text { forms in the life cycle of trypanosomes) }\end{array}$ \\
\hline$A B C G I$ & $21 \mathrm{q} 22.3$ & 13 & 678 & NM0049I5 & Cholesterol transport \\
\hline
\end{tabular}


Table 2. Continued

\begin{tabular}{|c|c|c|c|c|c|}
\hline Gene & $\begin{array}{l}\text { Chromosome } \\
\text { location }\end{array}$ & Exons & AA & $\begin{array}{l}\text { Accession } \\
\text { number }\end{array}$ & Function \\
\hline$A B C G 2$ & $4 q 22$ & 16 & 655 & NM004827 & Toxicant efflux, drug resistance \\
\hline$A B C G 4$ & I Iq23.3 & 15 & 646 & NM022169 & $\begin{array}{l}\text { Found in macrophage, eye, brain and } \\
\text { spleen }\end{array}$ \\
\hline$A B C G 5$ & $2 p 21$ & II & 651 & NM022436 & Sterol transport \\
\hline$A B C G 8$ & $2 p 21$ & 10 & 673 & NM022437 & Sterol transport \\
\hline
\end{tabular}

Abbreviations: HGNC, HUGO Gene Nomenclature Committee; AA, number of amino acids; HDL, high density lipoprotein; CFTR, cysticfibrosis transmembrane conductance regulator gene; ATP, adenosine triphosphate; ALD, adrenoleukodystrophy.

Table 3. Human $A B C$ transporter pseudogenes (adapted and modified from Piehler et al. ${ }^{8}$ )

\begin{tabular}{|c|c|c|c|}
\hline $\begin{array}{l}\text { Parental } \\
\text { gene }\end{array}$ & Pseudogene & $\begin{array}{l}\text { Chromosomal } \\
\text { location }\end{array}$ & $\begin{array}{l}\text { Accession } \\
\text { number }\end{array}$ \\
\hline$A B C A 3$ & $A B C A / 7 P$ & $16 p \mid 3.3$ & DQ266102 \\
\hline$A B C A \mid O$ & $A B C A \mid O P$ & $4 p 16.3$ & AK024359 \\
\hline Abcal 4* & $A B C A / 4 P I$ & $16 p \mid 2.2$ & \\
\hline Abcal5* & $\begin{array}{l}A B C A \mid 5 P I \\
A B C A \mid 5 P 2\end{array}$ & $\begin{array}{l}16 p \mid 2.2 \\
|6 p| 2.1\end{array}$ & DR73 I46I \\
\hline$A B C B 4$ & $A B C B 4 P$ & $4 q 32.1$ & \\
\hline$A B C B / 0$ & $\begin{array}{l}A B C B / O P I \\
A B C B / O P 2 \\
A B C B / O P 3\end{array}$ & $\begin{array}{l}15 q \mid 1.2 \\
|5 q| 3.1 \\
15 q \mid 3.1\end{array}$ & \\
\hline$A B C C 6$ & $\begin{array}{l}A B C C 6 P 1 \\
A B C C 6 P 2\end{array}$ & $\begin{array}{l}16 p \mid 2.3 \\
16 p \mid 3.11\end{array}$ & DBII925 \\
\hline$A B C D /$ & $\begin{array}{l}A B C D / P \mid \\
A B C D / P 2 \\
A B C D / P 3 \\
A B C D / P 4\end{array}$ & $\begin{array}{l}2 p|| . \mid \\
10 p|| . \mid \\
16 p|| .2 \\
22 q|| . \mid\end{array}$ & AY344II \\
\hline$A B C E I$ & $\begin{array}{l}A B C E I P I \\
A B C E I P 2\end{array}$ & $\begin{array}{l}|q 3| .2 \\
7 p \mid 5.3\end{array}$ & \\
\hline$A B C F 2$ & $\begin{array}{l}A B C F 2 P I \\
A B C F 2 P 2\end{array}$ & $\begin{array}{l}3 p \mid 1.2 \\
7 q 11.2\end{array}$ & \\
\hline$A B C G 2$ & $\begin{array}{l}A B C G 2 P I \\
A B C G 2 P 2\end{array}$ & $\begin{array}{l}14 q 24.3 \\
15 q 23\end{array}$ & \\
\hline
\end{tabular}

*Abcal 4, Abcal 5 and Abcal 6 are mouse genes, with no human orthologues. ${ }^{9}$ The mouse genome contains $52 \mathrm{Abc}$ genes, whereas the human genome carries $49 \mathrm{ABC}$ genes.

\section{Subfamily $F$ of the ABC family (ABCF)}

Along with ABCE1, ABCF members also have ATP-binding domains, but no transmembrane domains, making transporter function unlikely. Due to alternatively spliced products, the three $A B C F$ genes encode 26 distinct proteins. ${ }^{10}$ Because the $A B C F$ genes appear to be upregulated by tumour necrosis factor- $\alpha$, it is believed that members of this subfamily might play a role in inflammatory processes. No diseases have been associated, so far, with either the $A B C E$ or $A B C F$ genes (Table 2).

\section{Subfamily $G$ of the $A B C$ family (ABCG)}

Subfamily G comprises at least five genes that encode 'reverse half-transporters', meaning that they form the second half of a heterodimer. Mutations in $A B C G$ genes have been implicated in sterol accumulation disorders and atherosclerosis (Table 2). Due to alternative splicing, at least 18 distinct subunit proteins have been identified as products of the five $A B C G$ genes. ${ }^{10}$ ABCG1 is involved in cholesterol efflux in macrophages and may regulate cellular lipid homeostasis in other cell types as well. ABCG2 functions in multidrug resistance transport; steroids (cholesterol, oestradiol, progesterone and testosterone) and certain chlorophyll metabolites, as well as organic anions, are transported by ABCG2. ABCG3 is expressed at high levels in the thymus and spleen, suggesting a possible potential role in the transport of specific 
peptides or hydrophobic compounds from lymphocytes. ABCG5 and ABCG8 both appear to limit intestinal absorption and promote biliary excretion of sterols; their expression is localised primarily in the liver, colon and intestine. Mutations in either of these two genes lead to sitosterolaemia. This is characterised by hyperabsorption plus decreased biliary excretion of dietary sterols, leading to hypercholesterolaemia, tendon and tuberous xanthomata, early-age onset of atherosclerosis, and abnormal blood and liver function test results.

\section{Evolution of the $A B C$ transporter family}

Clearly, the ancestral $A B C$ gene first appeared in unicellular organisms and is therefore ancient, being now present in eubacteria, archaebacteria, plants, fungi, yeast and all animals. The nomenclature of the $A B C$ gene family is the same as that developed for more than 150 other gene families and superfamilies in the human and rodent genomes (http://www.genenames.org/). All of these nomenclature systems followed the original example described for the CYP genes. The CYP genes were conveniently arranged into families and subfamilies based on percentage amino acid sequence identity. ${ }^{22-27}$ Enzymes that share $\sim 40$ per cent or higher identity are assigned to a particular family (designated by an Arabic numeral). Protein sequences sharing $\sim 55$ per cent or higher identity are grouped into a particular subfamily (designated by a letter). Enzymes that share greater than $\sim 70$ per cent amino acid identity are then named as members within that subfamily (and given Arabic numbers, usually in the sequence in which they were discovered).

For example, sterol 27-hydroxylase and 25-hydroxy-vitamin $\mathrm{D}_{3} 1 \alpha$-hydroxylase are both assigned to the CYP27 family because they share $>40$ per cent sequence identity. Because their protein sequences are $<55$ per cent identical, however, sterol 27-hydroxylase is assigned to the CYP27 'A' subfamily and 25-hydroxy-vitamin $\mathrm{D}_{3}$ $1 \alpha$-hydroxylase to the 'B' subfamily. If another enzyme were to be discovered that shared $>55$ per cent identity with sterol 27-hydroxylase, it would be named CYP27A2. Another enzyme was discovered that shared $<55$ per cent but $>40$ per cent identity with sterol 27-hydroxylase, as well as with the 25-hydroxy-vitamin $\mathrm{D}_{3} 1 \alpha$-hydroxylase, and therefore it was named CYP27C1. The development and application of this pleasingly logical system of nomenclature to the genes of many animals, plants and bacteria (http://drnelson. utmem.edu/CytochromeP450.html) has eliminated the confusion that often has plagued the naming of gene families and superfamilies. Subsequently, this 'divergent evolution' nomenclature system has been adopted for the $A B C$ gene family, among many others. The human subfamilies and members within each subfamily can be seen (Figure 1) to have diverged over evolutionary time. The nomenclature for both the human $A B C$ gene family and the CYP gene superfamily has been approved by the HUGO Gene Nomenclature Committee (HGNC; http://www.genenames.org).

\section{Conclusions}

The family of ABC pumps, along with the superfamily of SLC proteins summarised in the last issue of Human Genomics, ${ }^{2}$ are among the most important large classes of transporters that move inorganic ions, metals, peptides, steroids, nucleosides, sugars and many other small molecules across the cell's surface membrane, as well as organelle membranes within cells. The $A B C$ gene family of transporters comprises 49 and 52 genes (in eight subfamilies) in the human and mouse genomes, respectively; the nomenclature of these genes is based strictly on divergent evolution. The SLC gene superfamily is composed of 362 genes in 55 families in the human genome; the nomenclature of those genes is based largely on biochemical function, rather than divergent evolution from a common ancestor. ${ }^{2}$

The ABC transporters are critically important in innumerable physiological functions, underscored by the fact that defects in more than a dozen of these genes have been associated with severe inherited disorders of metabolism - cystic fibrosis being among the most prominent diseases, caused by 
mutations in the CFTR gene. The ABC transporters are also of great clinical importance in the transport of cancer chemotherapeutics, numerous other drugs and metabolites, and many chemicals present in foodstuffs. ABC transporters are therefore likely targets for drug therapy. A large number of new studies focused on the ABC transporter genes are anticipated.

\section{Acknowledgments}

We thank our colleagues, especially Lei $\mathrm{He}$, for valuable discussions and a careful reading of this manuscript. The writing of this paper was funded, in part, by NIH grants R01 EY11490 (V.V.) and P30 ES06096 (D.W.N.).

\section{References}

1. Camerino, D.C., Desaphy, J.F., Tricarico, D. et al. (2008), 'Therapeutic approaches to ion channel diseases', Adv. Genet. Vol. 64, pp. 81-145.

2. He, L., Vasiliou, K. and Nebert, D.W. (2009), 'Analysis and update of the human solute carrier (SLC) gene superfamily', Hum. Genomics Vol. 3, pp. 195-206.

3. Benga, G. (2009), 'Water channel proteins (later called aquaporins) and relatives: Past, present, and future', IUBMB Life Vol. 61, pp. 112-133.

4. Verrier, P.J., Bird, D., Burla, B. et al. (2008), 'Plant ABC proteins - A unified nomenclature and updated inventory', Trends Plant Sci. Vol. 13, pp. $151-159$.

5. Dassa, E. and Bouige, P. (2001), 'The ABC of ABCs: A phylogenetic and functional classification of ABC systems in living organisms', Res. Microbiol. Vol. 152, pp. 211-229.

6. Orsi, C.H. and Tanksley, S.D. (2009), 'Natural variation in an $A B C$ transporter gene associated with seed size evolution in tomato species', PLoS Genet. Vol. 5, p. e1000347.

7. Lage, H. (2008), 'An overview of cancer multidrug resistance: A still unsolved problem', Cell. Mol. Life Sci. Vol. 65, pp. 3145-3167.

8. Piehler, A.P., Hellum, M., Wenzel, J.J. et al. (2008), 'The human ABC transporter pseudogene family: Evidence for transcription and gene-pseudogene interference', BMC Genomics Vol. 9, p. 165.

9. Chen, Z.Q., Annilo, T., Shulenin, S. and Dean, M. (2004), 'Three ATP-binding cassette transporter genes, Abca14, Abca15, and Abca16, form a cluster on mouse chromosome 7F3', Mamm. Genome Vol. 15, pp. 335-343.

10. Dean, M., Rzhetsky, A. and Allikmets, R. (2001), 'The human ATP-binding cassette (ABC) transporter superfamily', Genome Res. Vol. 11, pp. 1156-1166.
11. Finn, R.D., Mistry, J., Schuster-Bockler, B. et al. (2006), 'Pfam: Clans, web tools and services', Nucl. Acids Res. Vol. 34, pp. D247-D251.

12. Finn, R.D., Tate, J., Mistry, J. et al. (2008), 'The Pfam protein families database', Nucl. Acids Res. Vol. 36, pp. D281-D288.

13. Albrecht, C. and Viturro, E. (2007), 'The ABCA subfamily - Gene and protein structures, functions and associated hereditary diseases', Pflugers Arch. Vol. 453, pp. 581-589.

14. Nebert, D.W., Zhang, G. and Vesell, E.S. (2008), 'From human genetics and genomics to pharmacogenetics and pharmacogenomics: Past lessons, future directions', Drug Metab. Rev. Vol. 40, pp. 187-224.

15. Voight, B.F., Kudaravalli, S., Wen, X. and Pritchard, J.K. (2006), 'A map of recent positive selection in the human genome', PLoS Biol. Vol. 4, p. e72.

16. Sabeti, P.C., Varilly, P., Fry, B. et al. (2007), 'Genome-wide detection and characterization of positive selection in human populations', Nature Vol. 449, pp. 913-918.

17. Tang, K., Thornton, K.R. and Stoneking, M. (2007), 'A new approach for using genome scans to detect recent positive selection in the human genome', PLoS Biol. Vol. 5, p. e171.

18. Miki, Y., Suzuki, T., Tazawa, C. et al. (2005), 'Steroid and xenobiotic receptor (SXR), cytochrome P450 3A4, and multidrug resistance gene 1 in human adult and fetal tissues', Mol. Cell. Endocrinol. Vol. 231, pp. $75-85$.

19. Krasowski, M.D., Yasuda, K., Hagey, L.R. and Schuetz, E.G. (2005), 'Evolution of the pregnane $\mathrm{X}$ receptor: Adaptation to cross-species differences in biliary bile salts', Mol. Endocrinol. Vol. 19, pp. $1720-1739$.

20. Jordan, I.K., Kota, K.C., Cui, G. et al. (2008), 'Evolutionary and functional divergence between the cystic fibrosis transmembrane conductance regulator and related ATP-binding cassette transporters', Proc. Natl. Acad. Sci. USA Vol. 105, pp. 18865-18870.

21. Kavic, S.M., Frehm, E.J. and Segal, A.S. (1999), 'Case studies in cholera: Lessons in medical history and science', Yale J. Biol. Med. Vol. 72, pp. 393-408.

22. Nebert, D.W. and Gonzalez, FJ. (1987), 'P450 genes: Structure, evolution, and regulation', Annu. Rev. Biochem. Vol. 56, pp. 945-993.

23. Nebert, D.W., Adesnik, M., Coon, M.J. et al. (1987), 'The P450 gene superfamily. Recommended nomenclature', DNA Vol. 6, pp. 1-11.

24. Nebert, D.W., Nelson, D.R., Adesnik, M. et al. (1989), 'The P450 superfamily: Updated listing of all genes and recommended nomenclature for the chromosomal loci', $D N A$ Vol. 8, pp. 1-13.

25. Nebert, D.W., Nelson, D.R., Coon, M.J. et al. (1991), 'The P450 superfamily: Update on new sequences, gene mapping, and recommended nomenclature', DNA Cell Biol. Vol. 10, pp. 1-14.

26. Nelson, D.R., Kamataki, T., Waxman, D.J. et al. (1993), 'The P450 superfamily: Update on new sequences, gene mapping, accession numbers, early trivial names of enzymes, and nomenclature', DNA Cell Biol. Vol. 12, pp. 1-51.

27. Nelson, D.R., Koymans, L., Kamataki, T. et al. (1996), 'P450 superfamily: Update on new sequences, gene mapping, accession numbers and nomenclature. Pharmacogenetics Vol. 6, pp. 1-42. 